\title{
Improving Global Wash Sustainability
}

\author{
Graydon, R.C.'
}

'Department of Global Health, College of Public Health, University of South Florida, USA. Corresponding author: rgraydon@health.usf.edu

\section{Abstract}

This paper provides a review of the health and economic effects of water, health, and sanitation (WASH) infrastructure. Global strategies to increase WASH infrastructure and the current coverage levels are discussed revealing mixed progress and disparities particularly in rural areas. Many rural WASH infrastructure interventions have failed or operate significantly below intended capacity demonstrating the need for a greater focus on sustainability. This paper defines sustainability in the context of WASH infrastructure and describes the tools used to assess sustainability of water projects. Finally, this paper concludes with specific recommendations for governments, nongovernmental organizations, and donors to improve the sustainability of water projects and ultimately the development of communities.

Keywords: sustainable development goals, water, sanitation, hygiene, global health, development.

\section{Introduction}

Depending on one's point of view and situation, water, sanitation, and hygiene (WASH) services contain the ability to sustain healthy life and positive development (NAUGES; STRAND, 2013; WHO, 2012) or, on the other hand, developmental determent and cause of one's suffering and untimely death (FERDOUS et al., 2013; GUERRANT; DEBOER; MOORE; SCHARF; LIMA, 2013; HASANAIN; JAMSIAH; ZALEHA; AZMI; MOHAMMED, 2012; PRÜSS-USTÜN et al., $2014)$. Sustainable WASH services is crucial to ensure its effectiveness and long-term benefits (BOULENOUAR; SCHWEITZER; 
LOCKWOOD, 2013; KWANGWARE; MAYO; HOKO, 2014; MCCONVILLE; MIHELCIC, 2007; RONDI; SORLINI; COLLIVIGNARELLI, 2015; SCHWEITZER; MIHELCIC, 2012).

\section{Health and Economic Consequences}

The lack of adequate WASH services poses the paramount threat to the health and development of the global community. Improper WASH causes a variety of diseases including diarrheal diseases, dracunculiasis, and lymphatic filariasis through the ingestion of pathogenic organisms in drinking water and unsanitary soil with pathogens such as Entamoeba histolytica, Giardia duodenalis, and Ascaris lumbricoides(GEERS CHILDERS; PALMIERI; SAMPSON; BRUNET, 2014). In terms of effect on health, inadequate WASH was estimated to be the cause of 842,000 diarrhea deaths globally representing $58 \%$ of diarrheal diseases in 2012 (PRÜSS-USTÜN et al., 2014), which is approximately 2,300 deaths per day. An estimated 361,000 deaths among children under five years of age, representing 5.5\% of deaths in that age group, could have been prevented with proper WASH. Persistent diarrhea among children is associated with malnutrition, cognitive impairment (FERDOUS et al., 2013; HASANAIN et al., 2012), and an increased risk of developing obesity later in life (GUERRANT et al., 2013). Proper WASH is crucial to a healthy life and development.
Concerning effect on development, the water crisis ranks number one in terms of global societal impact and number eight in terms of likelihood to occur within the next ten years (WEF, 2015). Lack of a clean drinking water source poses such a great economic threat due to the resulting mortality, morbidity, and disability by rendering a person unable to work and due to the enormous quantity of time demanded to haul water. Women and children bear the majority of the water hauling responsibilities with the largest group spending more than 30 minutes on a single trip totaling an estimated 140 million hours every day hauling water (UNICEF; WHO, 2015). This daily time demand causes obvious conflict with development by reducing time invested in an income-generating job, caring for family members, or attending school. However, through improved water sources and, thus, reduced hauling times, children's school attendance has significantly increased in multiple developing countries (NAUGES; STRAND, 2013). Investing in WASH infrastructure also has a high rate of return with an estimated US\$ 4 economic return on every US\$ 1 spent by keeping people healthy and productive (WHO, 2012). Investing in adequate WASH infrastructure would greatly reduce this burden of disease and provide enormous economic benefits.

\section{Global Framework for Solutions}

Clean water and sanitation is a building block to global public health 
and development as evidenced by its inclusion in the Millennium Development Goals (MDGs) and now the Sustainable Development Goals (SDGs). On September 25,2015 , the member states of the United Nations celebrated the beginning of a new era of cooperation in development with the adoption of the SDGs for 2030 (UNITED NATIONS, 2015). The SDGs are the post-2015 goals that follow the MDGs, which was the framework of development between 2000 to 2015 (UNITED NATIONS, 2000). The MDGs contained eight broad goals of which MDG 7c was to halve the proportion of people without sustainable access to safe drinking water and basic sanitation between 1990 and 2015 . Well ahead of the 2015 deadline, the goal for improved drinking water was announced as being met and surpassed in 2010 (UNICEF; WHO, 2012). However, this announcement was criticized as being overly optimistic when the microbial water quality was considered revealing improved water supplies with unsafe levels of coliforms in several countries raising serious concerns about the safety of the improved water sources (BAUM; KAYSER; STAUBER; SOBSEY, 2014; SHAHEED; ORGILL; MONTGOMERY; JEULAND; BROWN, 2014). This suggests new efforts are needed to ensure both quantity and quality of improved water sources.

When the final MDGs assessment report was published in 2015, it boasted numerous significant improvements but also revealed areas of needed improvement (UNICEF; WHO, 2015). Concerning drinking water, key positive highlights were that $91 \%$ of the global population was measured as using an improved water source and 2.6 billion people gained access to an improved water source since 1990. On the other hand, an unachieved goal was that the Caucasus and Central Asia, Northern Africa, Oceania, and Sub-Saharan Africa regions did not achieve their regional coverage goals. Specific disparities were noticed as $96 \%$ of the global urban population uses improved drinking water sources compared to only $84 \%$ of the global rural population. Stated another way, 8 out of 10 people without an improved drinking water source live in rural areas. As of the report's publishing, 663 million people still lack an improved drinking water source. Despite the global increase of improved rural water systems, evidence shows that $30-40 \%$ of these systems fail or operate significantly below intended capacity demonstrating the need for a greater focus on sustainability (LOCKWOOD; SMITS; SCHOUTEN; MORIARTY, 2010).

Concerning sanitation, the target of 77\% improved sanitation coverage was missed by almost 700 million people (UNICEF; WHO, 2015). Geographic disparities also exist in improved sanitation coverage as $82 \%$ of urban population was reported to have access to an improved sanitation facility compared to only $51 \%$ of rural population. Of those who lack access to an improved sanitation facility, 7 out of 10 live in rural areas, and 9 out of 10 people who practice open defecation live in rural areas. Although this target was not achieved, a highlight is that 2.1 billion people gained access to improved 
sanitation since 1990. However, 2.4 billion people still lack access to an improved sanitation facility. Based on this report, the SDGs were created to continue this progress.

There are 17 SDGs set to be achieved by 2030. SDG six is "Clean Water and Sanitation." Addressing drinking water and sanitation, target 6.1 is to "achieve universal and equitable access to safe and affordable drinking water for all" and target 6.2 is to "achieve access to adequate and equitable sanitation and hygiene for all and end open defecation..." (UNITED NATIONS, 2015). There are several other targets under this goal but these targets are relevant for the scope of this paper.

\section{Interventions: Focus on Sustainability}

The goal in providing WASH services is to ensure the entire array of benefits while minimizing its costs over time. Sustainable development has been defined as "development that meets the needs of current generations without compromising the ability of future generations to meet their own needs" (WCED, 1987, p. 43). Thus, sustainable WASH infrastructure is the continued delivery of clean drinking water and sanitation without resource depletion. How to best ensure sustainability is highly debated but one recurring theme is demand-driven approach (DAYAL; VAN WIJK; MUKHERJEE, 2000; KWANGWARE et al.,
2014; MADRIGAL; ALPÍZAR; SCHLÜTER, 2011 ; MONTGOMERY; BARTRAM; ELIMELECH, 2009).

\section{Demand-driven approach}

Demand-driven approach is the principle that local communities are active in the decisions that affect their communities and the consideration that different user groups may desire different interventions (DAYAL et al., 2000; MADRIGAL et al., 2011). Evidence has revealed that community participation in the design, financing, and administration significantly increases project sustainability (BARNES; ASHBOLT; ROSER; BROWN, 2014; MADRIGAL et al., 2011 ; MARKS; KOMIVES; DAVIS, 2014). Depth, not breadth, of resident's involvement in the planning process is associated with water point sustainability. Project outcomes are better when the community participates more in management decisions and less favorably with technical decisions (MARKS et al., 2014).The opposite of demand-driven approach is the supply-driven approach in which communities are not included in the decision-making process but are simply observers. Supply-driven approach, a paternalistic behavior, perpetuates cyclical poverty and ineffective interventions (CORBETT; FIKKERT, 2014). To improve sustainability outcomes, sustainability frameworks and assessment tools have been developed to guide and measure sustainable development. 


\section{Sustainabi 1 ity}

assessment tools

Dozens of sustainability assessment tools have been made to improve the sustainability of development projects addressingall stages of the planning and life cycle utilizing various sustainability models. The sustainability assessment tools contain a litany of questions based on its specific model of sustainability framework rating the likelihood of success and sustainability. Schweitzer, Grayson, and Lockwood (2014) performed a review of 191 sustainability assessment tools evaluating the context of their use and their strengths and weaknesses. Their review should be used as a resource in choosing the proper tool for the anticipated project. Besides these sustainability assessment tools, other specific recommendations exist for various groups that provide WASH infrastructure.

\section{Recommendations for governments}

According to Boulenouar and Schweitzer(2015), governments should develop an infrastructure asset management (IAM) strategy particularly for rural water supply where parastatal corporations and community management organizations manage the majority of WASH infrastructure. IAM in the WASH sector refers to the physical components of water systems as well as the decisions and processes to assure services. The government should also provide template contracts between service authorities and service providers and ensure the financing of WASH infrastructure. Lastly, government should provide the technical support and training to both service authorities and service providers. Evidence suggests that access to post-construction support services greatly affects sustainability outcomes (FERDOUS et al., 2013; MARKS et al., 2014). Although government financing is suggested, strong government subsidies have many drawbacks and may not appropriate for every project (GOMES; HELLER; CAIRNCROSS; DOMENÈCH; PENA, 2014). A more effective financing method to the financial recovery and functionality of installed water systems is the collection of a user fee (FOSTER, 2013; MONTGOMERY et al., 2009).

\section{Recommendations for non-governmental organizations and donors}

Boulenouar and Schweitzer (2015) suggest that non-governmental organizations (NGOs) can improve the sustainability of WASH infrastructure by supporting local governments to inventory the water assets in their jurisdiction and to implement the national IAM guidelines. Donors should also support the government by providing technical and financial support, ensuring all the water assets are registered, and sharing pertinent information. Many studies have demonstrated that the use 
of financial tools are beneficial to project sustainability (BOULENOUAR et al., 2013; JONES, 2013; KWANGWARE et al., 2014; MADRIGAL et al., 201 1; RONDI et al., 2015; SCHWEITZER; MIHELCIC, 2012). These three levels of organizations working together can provide greater accountability and local support, which increases project sUstainability (JONES, 2013; SMITS; ROJAS; TAMAYO, 2013; WINTERS, 2010).

\section{Conclusion}

In order to achieve SGD six and to reduce the rates of death and disease as well as its associated economic

\section{References}

BARNES, R., ASHBOLT, N., ROSER, D. and BROWN, P., 2014. Implementing sustainable water and sanitation projects in rural, developing communities. Waterlines, vol. 33, no. 1, pp. 71-88. https://doi. org/10.3362/1756-3488.2014.008

BAUM, R., KAYSER, G., STAUBER, C. and SOBSEY, M., 2014. Assessing the microbial quality of improved drinking water sources: Results from the Dominican Republic. The American Journal of Tropical Medicine and Hygiene, vol. 90, no. 1, pp. 121-123. https:// doi.org/10.4269/ajtmh.13-0380

BOULENOUAR, J. and SCHWEITZER, R., 2015. Infrastructure asset management for rural water supply. Avaiable from: http://www.ircwash.org/ resources/infrastructure-asset-management-ruralwater-supply.

BOULENOUAR, J., SCHWEITZER, R. and LOCKWOOD, H., 2013. Mapping sustainability assessment tools to support sustainable water and sanitation service delivery. IRC International Water and Sanitation Centre, The Hague, the Netherlands. Avaiable from: http://www.ircwash.org/sites/default/files/2013_ wp6_sustainabilityassessmenttools.pdf consequences, WASH services and infrastructure must be built especially in the areas where it is lacked most and disease is most prevalent, namely rural areas. Simply providing WASH infrastructure (i.e. supply-driven demand) to communities in need has resulted in inoperable systems and the perpetuation of poverty foiling development efforts(Lockwood et al., 2010). Therefore, through the recommendations of demand-driven approach and usage of sustainability assessment tools, new WASH infrastructure can provide lasting health benefits and support the economic development of the recipient communities in both rural and urban areas.

CORBETT, S. and FIKKERT, B., 2014. When Helping Hurts: How to Alleviate Poverty Without Hurting the Poor... and Yourself (New Edition). Chicago, IL: Moody Publishers.

DAYAL, R., VAN WIJK, C. and MUKHERJEE, N., 2000. Methodology for participatory assessments with communities, institutions, and policymakers : linking sustainability with demand, gender, and poverty, no. 20831, pp. 1-120. The World Bank. Avaiable from: http://documents.worldbank.org/curated/ en/2000/03/693353/methodology-participatoryassessments-communities-institutions-policymakerslinking-sustainability-demand-gender-poverty

FERDOUS, F. et al., 2013. Severity of diarrhea and malnutrition among under five-year-old children in rural Bangladesh. The American Journal of Tropical Medicine and Hygiene, vol. 89, no. 2, pp. 223-228. https://doi.org/10.4269/ajtmh.12-0743

FOSTER, T., 2013. Predictors of sustainability for community-managed handpumps in Sub-Saharan Africa: Evidence from Liberia, Sierra Leone, and Uganda. Environmental Science \& Technology, vol. 47, no. 21, pp. 12037-12046. https://doi.org/10.1021/ es402086n 
GEERS CHILDERS, K.A., PALMIERI, J., SAMPSON, M. and BRUNET, D., 2014. Prevalence of gastrointestinal parasites in children from Verón, a rural city of the Dominican Republic. Research and Reports in Tropical Medicine, vol. 5, pp. 45-53. https://doi. org/10.2147/RRTM.S64948

GOMES, U., HELLER, L., CAIRNCROSS, S., DOMENÈCH, L. and PENA, J., 2014. Subsidizing the sustainability of rural water supply: the experience of the Brazilian rural rainwater-harvesting programme. Water International, vol. 39, no. 5, pp. 606-619. https:// doi.org/10.1080/02508060.2014.951255

GUERRANT, R., DEBOER, M., MOORE, S., SCHARF, R. and LIMA, A., 2013. The impoverished gut-a triple burden of diarrhoea, stunting and chronic disease. Nature Reviews Gastroenterology and Hepatology, vol. 10, no. 4, pp. 220-229. https://doi.org/10.1038/ nrgastro.2012.239

HASANAIN, F., JAMSIAH, M., ZALEHA, M., AZMI, M.T. and MOHAMMED, A., 2012. Association between drinking water sources and diarrhea with malnutrition among kindergarten's children in Baghdad City, Iraq. Malaysian Journal of Public Health Medicine, vol. 12, no. 1, pp. 45-48.

JONES, S., 2013. How can INGOs help promote sustainable rural water services? An analysis of WaterAid's approach to supporting local governments in Mali. Water Alternatives, vol. 6, no. 3, pp. 350-366.

KWANGWARE, J., MAYO, A. and HOKO, Z., 2014. Sustainability of donor-funded rural water supply and sanitation projects in Mbire district, Zimbabwe. Physics and Chemistry of the Earth, Parts A/B/C, pp. 76-78, pp. 134-139. https://doi.org/10.1016/j. pce.2014.10.001

LOCKWOOD, H., SMITS, S., SCHOUTEN, T. and MORIARTY, P., 2010. Providing sustainable water services at scale. IRC and Aguaconsult. Avaiable from: http://www.ircwash.org/sites/default/files/ Lockwood-2010-Providing.pdf

MADRIGAL, R., ALPÍZAR, F. and SCHLÜTER, A., 2011. Determinants of performance of community-based drinking water organizations. World Development, vol. 39, no. 9, pp. 1663-1675. https://doi.org/10.1016/j. worlddev.2011.02.011

MARKS, S., KOMIVES, K. and DAVIS, J., 2014. Community participation and water supply sustainability: Evidence from handpump projects in rural Ghana. Journal of Planning Education And Research, vol. 34, no. 3, pp. 276-286. https://doi.org/10.1177/0739456X14527620
McCONVILLE, J.R. and MIHELCIC, J.R., 2007. Adapting life-cycle thinking tools to evaluate project sustainability in international water and sanitation development work. Environmental Engineering Science, vol. 24, no. 7, pp. 937-948. https://doi.org/10.1089/ ees.2006.0225

MONTGOMERY, M.A., BARTRAM, J. and ELIMELECH, M., 2009. Increasing functional sustainability of water and sanitation supplies in rural Sub-Saharan Africa. Environmental Engineering Science, vol. 26, no. 5, pp. 1017-1023. https://doi.org/10.1089/ees.2008.0388

NAUGES, C. and STRAND, J., 2013. Water hauling and girls' school attendance: Some new evidence from Ghana. The World Bank. Avaiable from: http://elibrary. worldbank.org/doi/abs/10.1596/1813-9450-6443

PRÜSS-USTÜN, A. et al., 2014. Burden of disease from inadequate water, sanitation and hygiene in low- and middle-income settings: A retrospective analysis of data from 145 countries. Tropical Medicine \& International Health, vol. 19, no. 8, pp. 894-905. https://doi.org/10.1111/tmi.12329

RONDI, L., SORLINI, S. and COLLIVIGNARELLI, M.C., 2015. Sustainability of water safety plans developed in Sub-Saharan Africa. Sustainability, vol. 7, no. 8, pp. 11139-11159. https://doi.org/10.3390/su70811139

SCHWEITZER, R., GRAYSON, C. and LOCKWOOD, H., 2014. Mapping of Water, Sanitation, and Hygiene Sustainability Tools. IRC and Aguaconsult. Avaiable from: http://www.ircwash.org/sites/default/files/ triple-s_wp10mappingofwashsustainabilitytools.pdf

SCHWEITZER, R.W. and MIHELCIC, J.R., 2012. Assessing sustainability of community management of rural water systems in the developing world. Journal of Water, Sanitation and Hygiene for Development, vol. 2, no. 1, p. 20. https://doi.org/10.2166/washdev.2012.056 SHAHEED, A., ORGILL, J., MONTGOMERY, M., JEULAND, M. and BROWN, J., 2014. Why "improved" water sources are not always safe. Bulletin of the World Health Organization, vol. 92, pp. 283-289. https:// doi.org/http://dx.doi.org/10.2471/BLT.13.119594

SMITS, S., ROJAS, J. and TAMAYO, P., 2013. The impact of support to community-based rural water service providers: Evidence from Colombia. Water Alternatives, vol. 6, no. 3, pp. 384-404. 
UNICEF, WHO, 2012. Millennium Development Goal drinking water target met. Avaiable from: http:// www.who.int/mediacentre/news/releases/2012/ drinking_water_20120306/en/. Access: Oct. 2015.

UNICEF, WHO, 2015. Progress on Sanitation and Drinking Water: 2015 Update and MDG Assessment. United States of America: UNICEF. Avaiable from: http://www.unicef.org/publications/index_82419.html

UNITED NATIONS, 2000. Millennium Summit. Avaiable from: http://www.un.org/en/events/pastevents/ millennium_summit.shtml. Access: Oct. 2015.

UNITED NATIONS, 2015. Sustainable Development Goals. Avaiable from: http://www.un.org/ sustainabledevelopment/sustainable-developmentgoals/. Access: Oct. 2015.

WHO, 2012. Global costs and benefits of drinkingwater supply and sanitation interventions to reach the MDG target and universal coverage. Geneva, Switzerland: WHO Document Production Services. Avaiable from: http://www.who.int/water_sanitation_ health/publications/2012/global_costs/en/
WINTERS, M.S., 2010. Accountability, participation and foreign aid effectiveness. International Studies Review, vol. 12, no. 2, pp. 218-243. https://doi. org/10.1111/j.1468-2486.2010.00929.x

WCED, 1987. World Commission on Environment and Development. Our Common Future (p. 300). Oxford, United Kingdom: Oxford University Press. Avaiable from: http://www.un-documents.net/ourcommon-future.pdf

WEF, 2015. World Economic Forum. The Global Risks 2015 Report. Avaiable from: http://reports.weforum. org/global-risks-2015/. Access: October 2015. 